УдК 637.523

DOI https://doi.org/10.32851/tnv-tech.2021.3.8

\title{
ОЦІНКА ПОКАЗНИКІВ ІКРИ ОЗДОРОВЧОГО СПРЯМУВАННЯ 3 ГАРБУЗУ ЗА РЕЗУЛЬТАТАМИ ЗАМІНИ ТЕХНОЛОГІЧНОГО ПРОЦЕСУ
}

\author{
Воєвода Н.В. - кандидат технічних наук, \\ старший викладач кафедри інженерії харчового виробництва \\ Херсонського державного аграрно-економічного університету \\ ORCID ID: 0000-0002-3324-965X \\ Радченко В.С. - студент II курсу біолого-технологічного фракультету \\ Херсонського державного аграрно-економічного університету \\ ORCID ID: 0000-0002-9641-2127
}

\begin{abstract}
У статті розглянуто показники якості розроблених зразків продукиії «Ікра овочева» з використанням технологічних змін виробництва для отримання оздоровчого харчування. Це зумовлено необхідністю забезпечити раціон певних груп населення та розширити асортимент підприємства. Так, із проривом нових технологій наразі багато шкідливих речовин, які містяться в їжі, спричиняють захворювання кишково-цлункового тракту, а иее унеможливлює вживання певних продуктів. Одним із факторів виникнення такого ефекту можуть бути шкідливі технологічні прочеси вироблення. Заміна класичних операцій є дуже важливою для забезпечення споживання тієї продукції, яка не буде икодити здоров'ю.
\end{abstract}

За результатами проведених досліджень визначено, щзо показники якості одержаної ікри оздоровчого спрямування з використанням прийому заміни технологічного процесу знаходяться в межах установлених законодавством норм. Тому можна стверджувати про відповідність отриманих зразків ДСТУ $3797-98$ за такими позиціями: зовнішній вигляд та консистенція, смак та запах, колір, сторонні домішки, масова частка жиру, масова частка сухих речовин за рефрактометром, масова частка хлоридів, титруєма кислотність у перерахунку на яблучну кислоту, масова частка мінеральних домішок.

Показано співвідношення вмісту білків, жирів та вуглеводів, калорійності. Якщо порівняти результат з даними класичної овочевої ікри з баклажанів, стає очевидно, щзо знизився вміст жирів з 9 г до 2,7 г, тобто на 70\%. Водночас калорійність готової продукиії зменшилась на 54,3\%, вміст вуглеводів збільшився на 18,47\% за рахунок природніх иукрів, шо містяться в гарбузі та чорносливі.

Отримані результати розрахунку економічної ефективності свідчать про можливість використання висунутих гіпотез стосовно технологічного процесу даного виду продукції в промисловому технологічному процесі, оскільки ичіна готової продукиії відповідає середній ціновій політиці. Варто зазначити, щчо продукція цінового лідеру не відповідає сучасним вимогам згідно з нормативною документацією.

Ключові слова: показники якості, овочева ікра, оздоровче харчування, модифікація, технологічний процуес.

Voievoda N.V., Radchenko V.S. Evaluation of caviar indicators from pumpkin for health direction according to the results of the replacement of the technological process

The article considers the quality indicators of the developed product samples "Vegetable Caviar" with the use of technological changes in production to obtain health food. This is due to the need to ensure the diet of certain groups and expand the range of enterprises. Thus, with the breakthrough of new technologies, there are now many harmful substances contained in food and cause diseases of the gastrointestinal tract, and this makes it impossible to eat certain foods. One of the factors of such effect can be harmful technological processes of production. Replacing classic operations is very important to ensure the consumption of products that will not be harmful to health.

According to the results of the research, it is determined that the quality indicators of the obtained caviar of health-improving direction with the use of the method of technological process replacement are within the norms established by the legislation. Therefore, we can 
say that the obtained samples accord DSTU 3797-98 on the following items: appearance and consistency, taste and smell, color, impurities, mass fraction of fat, mass fraction of dry matter by refractometer, mass fraction of chlorides, titratable acidity in terms of malic acid, mass fraction of mineral impurities.

The ratio of protein, fat and carbohydrate content in calories is shown. If we compare the result with the data of the classic vegetable caviar from eggplant, it is obvious that the fat content decreased from $9 \mathrm{~g}$ to $2.7 \mathrm{~g}$, ie by $70 \%$. At the same time, the caloric content of finished products decreased by $54.3 \%$, the carbohydrate content increased by $18.47 \%$ due to natural sugars contained in pumpkin and prunes.

The obtained results of the calculation of economic efficiency indicate the possibility of using the hypotheses regarding the technological process of this type of product in the industrial technological process, as the price of the finished product corresponds to the average pricing policy. It should be noted that the products of the price leader do not meet modern requirements according to regulatory documentation.

Key words: quality indicators, vegetable caviar, health food, modification, technological process.

Вступ. Переважна кількість населення вживає овочі в їжу як основний компонент раціону, а деякі люблять споживати овочеву ікру. Традиції приготування такої страви закладено ще з давніх часів. Із проривом технологій у сучасному світі можна розробити ікру, яка майже не буде шкодити організму як звичайної людини, так і з особливостями харчування.

Розроблення нових видів продукції - це шлях розвитку малих та середніх підприємств як на регіональному, так і на національному рівні. Особливо це стосується забезпечення потреб споживачів із хронічними захворюваннями. У зв'язку 3 цим доцільно розробляти не тільки нові асортименти, а й удосконалювати вже відомі. Прикладом є овочева ікра, в складі якої переважна більшість компонентів рецептури обсмажуються, що унеможливлює іiї вживання особам, які мають шлунково-кишкові порушення. Таким чином, питання заміни такого шкідливого технологічного процесу та розроблення доступної для дієтичного харчування продукції $є$ важливим та актуальним питанням, що необхідно вирішувати для забезпечення підтримки здоров'я нації. Як результат, постає проблема забезпечення відповідності якісних показників отриманої продукції нормативній документації.

Мета дослідження. Метою статті є визначення органолептичних та фізико-хімічних показників ікри оздоровчого спрямування, отриманої шляхом заміни технологічного процесу обжарювання та бланшування, для підтвердження доцільності їі виробництва.

Аналіз останніх досліджень і публікацій. Проблема покращення харчування спонукала до інноваційних досліджень багатьох учених, зокрема, М.Я. Бомба та С.Ю. Колодій оцінювали можливість адаптації калорійних традиційних вітчизняних страв до вимог дієтичного харчування у зв'язку з погіршенням стану здоров'я населення [1]. Відзначимо, що В.С. Іванченков та 3.В. Чехович розглядали питання популяризації здорового харчування через призму інновацій та стабільного економічного розвитку підприємств півдня України [2]. Зазначимо, що розробленням овочевої ікри підвищеної харчової цінності, до рецептури якої було введено нетрадиційну сировину - пюре 3 шипшини і пряно-ароматичну сировину - імбир та рапсову олію, займались Н.В. Дуденко і В.С. Ольховська [3]. Проте іiї основною сировиною $є$ кабачки, які піддаються термічній обробці шляхом обжарювання.

Виклад основного матеріалу. Зміна класичних компонентів дозволяє отримати новий за органолептичними показниками продукт, який не шкодить здоров'ю споживачів та може використовуватись у харчуванні осіб, що мають 
порушення функціонування шлунково-кишкового тракту і печінки. Це припущення базується на обгрунтованій з технологічної точки зору заміні класичного обжарювання сировини в паромасляній печі або печі Крапівіна на бланшування парою та водою. При цьому приємний присмак та післясмак готовій продукції надаватиме чорнослив [4].

Для аналізу розроблюваного асортименту консервів згідно із загальною схемою контролю технологічних параметрів виробництва використовувались методи, що вказані в табл. 1.

Таблиця 1

Методи, що використовувались під час дослідження технологічного процесу виробництва об'скта досліджень

\begin{tabular}{|c|c|c|c|}
\hline $\begin{array}{l}\text { № } \\
\text { 3/II }\end{array}$ & $\begin{array}{c}\text { Параметр, що } \\
\text { контролюється }\end{array}$ & $\begin{array}{c}\text { Нормативний } \\
\text { документ }\end{array}$ & Метод контролю \\
\hline 1 & Сировина & $\begin{array}{l}\text { ДСТУ2660-94, } \\
\text { ДСТУ 3190-95, } \\
\text { ДСТУ 3234-95, } \\
\text { ГОСТ 172185, } \\
\text { ДСТУ 2316-93, } \\
\text { ДСТУ } 3583-97\end{array}$ & $\begin{array}{l}\text { Органолептичний, титрометричний } \\
\text { метод, метод визначення домішок рос- } \\
\text { линного походження по масі та ін. }\end{array}$ \\
\hline 2 & Овочева ікра & $\begin{array}{l}\text { ГОСТ 28561-90, } \\
\text { ГОСТ 26183-84, } \\
\text { ГОСТ 26186-84, } \\
\text { ГОСТ 25555.0-82, } \\
\text { ГОСТ 24556-89, } \\
\text { ГОСТ 25555.3-82, } \\
\text { ГОСТ } 26323-84, \\
\text { ГОСТ } 30425-97\end{array}$ & $\begin{array}{l}\text { Потенціометричний, флотаційний, } \\
\text { термогравиметричний методи, ар- } \\
\text { гентометричний метод по фольгарду, } \\
\text { метод визначення домішок рослинного } \\
\text { походження по масі та ін. }\end{array}$ \\
\hline
\end{tabular}

Стандартом на готову продукцію передбачається нормування органолептичних та деяких фізико-хімічних показників якості овочевої ікри. Тому зразок із найкращими показниками дегустаційної оцінки досліджено в лабораторії ТОВ «Плодоовочевий комбінат «Херсон», а результати систематизовано в таблиці 2 у 2020 р.

Таблиця 2

Порівняння показників одержаних консервів 3 нормованими

\begin{tabular}{|l|l|l|}
\hline \multirow{2}{*}{$\begin{array}{c}\text { Найменування } \\
\text { показника }\end{array}$} & \multicolumn{1}{|c|}{$\begin{array}{c}\text { Овочевактеристика ікра відповідно } \\
\text { до ДСТУ 3797-98 }\end{array}$} & \multicolumn{1}{|c|}{$\begin{array}{c}\text { Ікра оздоровчого } \\
\text { спрямування }\end{array}$} \\
\hline 1 & \multicolumn{1}{|c|}{2} & \multicolumn{1}{|c|}{3} \\
\hline $\begin{array}{l}\text { Зовнішній вигляд } \\
\text { та консистенція }\end{array}$ & $\begin{array}{l}\text { Однорідна, рівномірно подрібнена } \\
\text { маса без грубого насіння, перезрі- } \\
\text { лих овочів і без видимого відділен- } \\
\text { ня рідини. Консистенція мажуча чи } \\
\text { трохи зерниста }\end{array}$ & $\begin{array}{l}\text { Iкра з мажучою кон- } \\
\text { систенцією без сторонніх } \\
\text { включень. Відділення } \\
\text { рідини не спостерігається }\end{array}$ \\
\hline Смак та запах & $\begin{array}{l}\text { Властивий ікрі, виробленій з ува- } \\
\text { рених баклажанів. Не допускається } \\
\text { присмак прогірклої олії та наяв- } \\
\text { ність сторонніх присмаку та запаху }\end{array}$ & $\begin{array}{l}\text { Гіркота не відчувається, } \\
\text { проте наявний копчений } \\
\text { аромат }\end{array}$ \\
\hline
\end{tabular}


Закінчення табл. 2

\begin{tabular}{|c|c|c|}
\hline 1 & 2 & 3 \\
\hline Колір & $\begin{array}{l}\text { Однорідний по всій масі від світло- } \\
\text { коричневого до коричневого }\end{array}$ & $\begin{array}{l}\text { Ікра коричневого кольору } \\
\text { по всій масі продукту }\end{array}$ \\
\hline Сторонні домішки & Не допускаються & Відсутні \\
\hline $\begin{array}{l}\text { Масова частка } \\
\text { жиру, \%, не менше }\end{array}$ & 9 & 9,5 \\
\hline $\begin{array}{l}\text { Масова частка } \\
\text { сухих речовин за } \\
\text { рефрактометром, } \\
\text { \% не менше, }\end{array}$ & $24 \%$ & $25,5 \%$ \\
\hline $\begin{array}{l}\text { Масова частка } \\
\text { хлоридів, \% }\end{array}$ & $1,2-1,6$ & 1,2 \\
\hline $\begin{array}{l}\text { Титруєма кислот- } \\
\text { ність у перера- } \\
\text { хунку на яблучну } \\
\text { кислоту, \%, не } \\
\text { більше }\end{array}$ & 0,5 & 0,35 \\
\hline $\begin{array}{l}\text { Масова частка } \\
\text { мінеральних домі- } \\
\text { шок, \%, не більше }\end{array}$ & 0,005 & 0,003 \\
\hline
\end{tabular}

Як очевидно з таблиці 2, отримані результати не перевищують установлених норм або знаходяться в їхніх межах. Тому можна вказати, що лабораторно отримані результати підтверджують відповідність ікри оздоровчого спрямування, одержаної відповідно до запропонованої рецептури та вибраної технологічної схеми виробництва, державним вимогам, викладеним у ДСТУ 3797-98.

Для обгрунтування результату заміни технологічного процесу обжарювання на бланшування та рецептурного складу ікри оздоровчого спрямування розраховано вміст співвідношення білків, жирів та вуглеводів у готовій продукції в отриманому четвертому зразку відповідно до прийнятої методики розрахунку і довідкових даних. Результати наведені на рис. 1 та в табл. 3 .

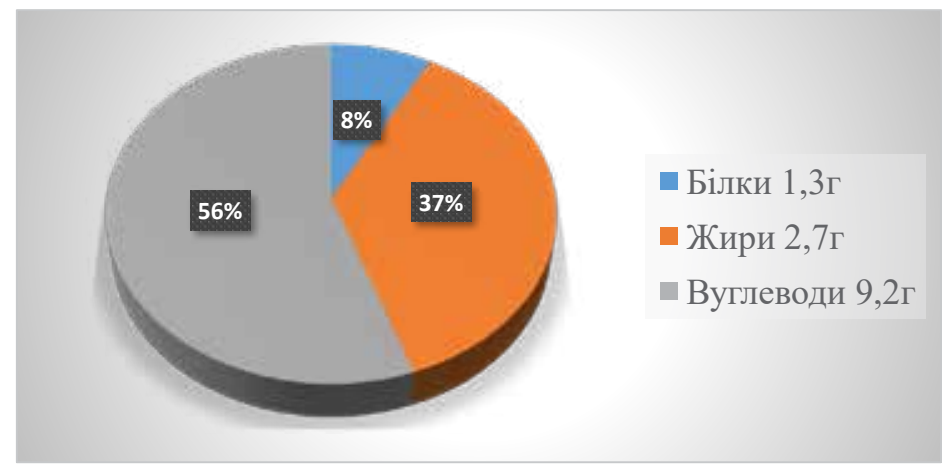

Рис. 1. Співвідношення білків, жирів та вуглеводів ікри оздоровчого спрямування в калорійності 
Якщо порівняти результат із даними класичної овочевої ікри з баклажанів, стає очевидно, що знизився вміст жирів з 9 г до 2,7 г, тобто на 70\%. Водночас калорійність готової продукції зменшилась на 54,3\%, вміст вуглеводів збільшився на $18,47 \%$ за рахунок природніх цукрів, що містяться в гарбузі та чорносливі.

Таблиця 3

Порівняльна характеристика вмісту макронутріснтів у одержаній продукції 3 класичними консервами

\begin{tabular}{|l|c|c|}
\hline \multicolumn{1}{|c|}{ Макронутріснти } & $\begin{array}{c}\text { Ікра оздоровчого } \\
\text { спрямування }\end{array}$ & $\begin{array}{c}\text { Овочева ікра відповідно } \\
\text { до ДСТУ 3797-98 }\end{array}$ \\
\hline Калорійність, ккал/100 г & 67,5 & 148 \\
\hline Білки, г & 1,3 & 1,2 \\
\hline Жири, г & 2,7 & 9,0 \\
\hline Вуглеводи, г & 9,2 & 7,5 \\
\hline Вода, г & 82 & - \\
\hline Харчові волокна, г & 2,8 & - \\
\hline
\end{tabular}

Розрахунок витрат прямих та непрямих матеріальних витрат показав, що собівартість однієї банки ікри оздоровчого спрямування в тарі I-82-500 становить 17,32 грн (37 640,88 грн за 1 т готової продукції). Тоді ціна цієї продукції з урахуванням націнки виробника у 40\% та 20\% податків становить:

$$
Ц=\left(C+\left(C \cdot \frac{0,4}{1}\right)\right) \cdot 1,2=\left(17,32+\left(17,32 \cdot \frac{0,4}{1}\right)\right) \cdot 1,2=29,10 г р н .
$$

Отримана розрахунком ціна є нижчою за ціну, яка існує на ринку України. Тобто досліджуваний товар може конкурувати з аналогічною продукцією імпортного та вітчизняного виробництва [5], яка присутня на ринку України, навіть із націнкою роздрібної торгівлі та транспортними витратами, адже середня ціна на ікру з баклажанів становить 34 грн/шт. Варто зазначити, що ціновим лідером є ТМ «С бабушкиной грядки», яка реалізовує продукцію по 24 грн, проте вона відзначається надто темним кольором та візуально очевидними неоднорідними включеннями, тому за рахунок цих недоліків ціну знижено.

Висновки і пропозиції. За результатами проведених досліджень визначено, що показники якості одержаної ікри оздоровчого спрямування з використанням прийому заміни технологічного процесу знаходяться в межах установлених законодавством норм. Тому можна стверджувати про відповідність отриманих зразків ДСТУ3797-98.

Як результат, отримані дані та результати розрахунку економічної ефективності свідчать про можливість використання висунутих гіпотез стосовно технологічного процесу даного виду продукції в промисловому технологічному процесі. Проте перспективами подальших досліджень є визначення промислової стерильності консервів.

\section{СПИСОК ВИКОРИСТАНОЇ ЛІТЕРАТУРИ:}

1. Бомба М.Я., Колодій С.Ю. Адаптація українських національних страв до сучасних вимог харчування. Новітні тенденциї у харчових технологіях та якість i безпечність. 2015. С. 127. 
2. Іванченков В.С., Чехович 3.В. Перспективи інноваційного розвитку консервного виробництва в Українському Причорномор’і. Економічні інновації. 2015. № 60 (1). С. $154-171$.

3. Дуденко Н.В., Ольховська В.С. Математичне моделювання овочевих консервів із заданими споживними властивостями. Вісник НТУ «ХПI». Серія: Нові рішення в сучасних технологіях. 2013. № 1 (977). С. 116-122.

4. Воєвода Н.В, Легутенко А.С. Оптимізація технології виробництва ікри оздоровчого спрямування з гарбузом. Вчені записки Таврійського начіонального університету імені В.І. Вернадського. Київ, 2020. Т. 31 (70). № 4. С. 208-212.

5 . Economic efficiency of textile materials cutting designer costumes of hospitality facilities / O. Dzyundzya et. al. VLAKNA a TEXTIL (FIBRES and TEXTILES). 2018. Vol. 25. Issue 4. P. 90-93.

\section{REFERENCES:}

1. Bomb, M.Ya., Kolodiy, S.Yu. (2015) Adaptation of Ukrainian national dishes to modern food requirements. The latest trends in food technology and quality and safety. P. 127. [in Ukranian]

2. Ivanchenkov V.S, Chekhovych Z.V (2015) Prospects for innovative development of canning production in the Ukrainian Black Sea coast. Economic innovations. 2015. № $(60$ (1)). P. 154-171. [in Ukranian]

3. Dudenko N.V., Olkhovskaya V.S. (2013) Mathematical modeling of canned vegetables with given consumer properties. Bulletin of NTU "KhPI". Series: New solutions in modern technologies. № 1 (977) P. 116-122. [in Ukranian]

4. Voevoda N.V., Legutenko A.S. (2020) Optimization of health caviar production technology with pumpkin. Scientific notes of Tavriya National University named after V.I. Vernadsky. Kiev. T. 31. № 4. P. 208-212. [in Ukranian]

5. Economic efficiency of textile materials cutting designer costumes of hospitality facilities / O. Dzyundzya, (2018) et. al. FIBERS and TEXTILES (FIBERS and TEXTILES). Vol. 25, Issue 4, P. 90-93. [in English] 